\title{
International heterogeneity in coronavirus disease 2019 pediatric mortality rates
}

\author{
Nadia González-García1', América L. Miranda-Lora², Juan Garduño-Espinosa3, \\ Javier T. Granados-Riverón ${ }^{4}$, Jorge F. Méndez-Galván ${ }^{5}$, Jaime Nieto-Zermeño ${ }^{6}$, and \\ Ma. Fernanda Castilla-Peón ${ }^{3 *}$ \\ ${ }^{1}$ Laboratorio de Investigación en Neurociencias; ${ }^{2}$ Unidad de Investigación en Medicina Basada en Evidencias; ${ }^{3}$ Dirección de Investigación; ${ }^{4}$ Unidad \\ de Investigación en Patogenésis Molecular; ${ }^{5}$ Unidad de Investigación en Enfermedades Emergentes; ${ }^{6}$ Dirección General. Hospital Infantil de México \\ Federico Gómez, Mexico City, Mexico
}

\begin{abstract}
Background: Severe coronavirus disease 2019 (COVID-19) is infrequent in children and shows a mortality rate of around $0.08 \%$. This study aims to explore international differences in the pediatric mortality rate. Methods: We analyzed several countries with populations over 5 million that report disaggregated data of COVID-19 deaths by quinquennial or decennial age groups. Data were extracted from COVID-19 cases and deaths by age database, National Ministeries of Health, and the World Health Organization. Results: We included 23 countries in the analysis. Pediatric mortality varied from 0 to 12.1 deaths per million children of the corresponding age group, with the highest rate in Peru. In most countries, deaths were more frequent in the 0-4-year-old age group, except for Brazil. The pediatric/general COVID-19 mortality showed a great variation and ranged from $0 \%$ (Republic of Korea) to $10.4 \%$ (India). Pediatric and pediatric/general COVID mortality correlates strongly with 2018 neonatal mortality $(r=0.77, p<0.001$; and $r=0.88, p<0.001$, respectively), while shows a moderate or no correlation ( $r=0.47, p=0.02$; and $r=0.19, p=0.38$, respectively) with COVID-19 mortality in the general population. Conclusions: International heterogeneity in pediatric COVID-19 mortality importantly parallels historical neonatal mortality. Neonatal mortality is a well-known index of the quality of a country's health system, which points to the importance of social determinants of health in pediatric COVID-19 mortality disparities. This issue should be further explored.
\end{abstract}

Key words: Coronavirus disease 2019. Mortality. Infant. Child. Adolescent. Geographic location.

\section{Heterogeneidad internacional en las tasas de mortalidad pediátrica por COVID-19}

\section{Resumen}

Introducción: La COVID-19 grave es poco frecuente en la infancia. El objetivo de este estudio fue explorar las diferencias en la tasa de mortalidad internacional por COVID-19 en la población pediátrica. Método: Se analizaron países con poblaciones superiores a 5 millones de habitantes que reporten muertes por COVID-19 con datos desglosados por grupos de edad quinquenales o decenales. Los datos se extrajeron de la base de datos COVerAge-DBs, de los ministerios nacionales de salud y de la Organización Mundial de la Salud. Resultados: Se incluyeron 23 países. La mortalidad pediátrica varió de 0 a 12.1 muertes por millón de personas del grupo de edad correspondiente, con la tasa más alta en Perú. En la mayoría de los

\section{Correspondence:}

*Ma. Fernanda Castilla-Peón

E-mail: fernandacastillapeon@gmail.com
Available online: 24-02-2021

Date of reception: $16-09-2020$

Date of acceptance: 03-10-2020

DOI: 10.24875/BMHIM.20000291
Bol Med Hosp Infant Mex. 2021;78(1):24-28

www.bmhim.com (http://creativecommons.org/licenses/by-nc-nd/4.0/) 
países, las muertes fueron más frecuentes en el grupo de 0 a 4 años, excepto en Brasil. La mortalidad pediátrica/general por COVID-19 mostró una gran variación entre países y osciló entre el 0\% (República de Corea) y el 10.4\% (India). La mortalidad pediátrica y pediátrica/general por COVID-19 se correlaciona fuertemente con la mortalidad neonatal de 2018, mientras que tiene una moderada o nula correlación con la mortalidad por COVID-19 en la población general. Conclusiones: Existe una importante heterogeneidad internacional en la mortalidad pediátrica por COVID-19, que es paralela a la mortalidad neonatal histórica, la cual es un indicador de la calidad de los sistemas de salud y señala la importancia de los determinantes sociales de la salud en las disparidades de mortalidad pediátrica por COVID-19. Este tema debe explorarse a fondo.

Palabras clave: COVID-19. Mortalidad. Niños. Adolescentes. Países.

\section{Introduction}

Since the first cases of coronavirus disease 2019 (COVID-19) appeared in Wuhan, China, morbidity and mortality by severe acute respiratory syndrome coronavirus 2 (SARS-CoV-2) have been significant in countries in every continent. Mortality is mostly concentrated in advanced age groups and the adult population with ongoing comorbidities ${ }^{1-5}$. Children and adolescents constitute $2 \%$ and $9.5 \%$ of all reported cases in Europe and the USA. Severe COVID-19 is infrequent in children, so intensive care unit admissions regarding this age group have been reported to be about $2 \%$ and mortality rate about $0.08 \%$. Besides, preliminary evidence suggests that both ethnicity (Black and Hispanic) and age (under 1 month and early adolescence [10-14 years]) are associated with admission to a critical care unit. Moreover, children from low-income families or non-White ethnicities are more likely to test positive for SARS-CoV-2 than White children and high-income families ${ }^{7,8}$.

Although some countries have published COVID-19 epidemiologic data in the pediatric population, the comparison among different populations is scarce. COVID-19 mortality in the population under 18 years of age might be heterogeneous between countries with different incomes and ethnicities. This brief report aimed to explore international differences in the COVID19 pediatric mortality rate.

\section{Methods}

We included information about countries with populations over 5 million that reported COVID-19 deaths disaggregated by quinquennial or decennial age groups. Data on confirmed COVID-19 death counts were consulted in the COVID-19 cases and deaths by age database (COVerAge-DB) ${ }^{9}$. COVerAge-DB collects age- and sex-specific cumulative cases, deaths, and tests from official reports from multiple countries worldwide and several subpopulations. Data from Argentina,
Canada, Peru, and Mexico were consulted from the local ministries of health ${ }^{10-13}$. Data from countries disaggregated by decennial age groups were estimated according to the countries' age structure available data.

For the computation of age-specific mortality rates, we obtained both total and quinquennial age groups estimated populations for 2018 or the latest available year from the United Nations Statistics Division web $\mathrm{site}^{14}$. Data for general COVID-19 mortality were extracted from the World Health Organization reports ${ }^{15}$. In an exploratory analysis, we also calculated the Spearman's correlation coefficient between pediatric COVID-19 mortality rates with general mortality rates and newborn mortality by any cause in 2018 (before the COVID-19 pandemic). STATA $13.0 \AA$ software was used for the analysis.

\section{Results}

We included 23 countries in the analysis. Table 1 shows the general mortality and pediatric mortality rates from COVID-19. Specifically, $63 \%$ of deaths in the $<15$ years of age population at the time of the study occurred in India $(n=1,622)$. However, when adjusting the mortality per million people for this age group, the highest rates were observed in Latin American countries (Peru, Brazil, Ecuador, and Mexico). Peru showed the highest overall COVID-19 mortality rate followed by European countries (the United Kingdom, Spain, and Italy). Furthermore, the highest pediatric to general population ratio of COVID-19 mortality was identified in Asian countries (India, Indonesia, and the Philippines).

Table 2 shows COVID-19 pediatric mortality by quinquennial age groups. The highest mortality in children under 10 years old was observed in Peru, and the highest mortality in children > 10 years old was in Brazil.

We found a significant correlation between both COVID-19 pediatric mortality and COVID-19 pediatric/ general mortality ratio and neonatal mortality in $2018(r=0.77, p<0.001$; and $r=0.88, p<0.001$, 
Table 1. COVID-19 mortality rates and neonatal mortality in 2018 by country

\begin{tabular}{|c|c|c|c|c|c|c|}
\hline \multirow[t]{2}{*}{ Country } & \multicolumn{4}{|c|}{ COVID-19 } & \multirow{2}{*}{$\begin{array}{l}\text { Neonatal } \\
\text { mortality (every } \\
\text { cause) per } 1000 \\
\text { alive newborns } \\
\text { in } 2018\end{array}$} & \multirow{2}{*}{$\begin{array}{c}\text { Data collection } \\
\text { date }\end{array}$} \\
\hline & $\begin{array}{c}\text { Deaths in the } \\
\text { population } \\
<15 \text { years of } \\
\text { age }\end{array}$ & $\begin{array}{c}\text { Mortality rate } \\
\text { in }<15 \text { years } \\
\text { of age per } \\
\text { million } \\
\text { people }\end{array}$ & $\begin{array}{l}\text { Mortality rate in } \\
\text { the general } \\
\text { population per } \\
\text { million people } \\
(23 / 08 / 20)\end{array}$ & $\begin{array}{l}\text { Pediatric/ } \\
\text { general } \\
\text { mortality } \\
\text { rate ratio } \\
(\%)\end{array}$ & & \\
\hline Peru & 94 & 12.1 & 852 & 1.4 & 7.3 & $09 / 08 / 2020$ \\
\hline Brazil $^{\text {ab }}$ & 405 & 8.8 & 541 & 1.6 & 8.1 & 02/08/2020 \\
\hline Ecuador ${ }^{b}$ & 25 & 5.5 & 367 & 1.5 & 7.2 & $13 / 08 / 2020$ \\
\hline Mexico & 169 & 5.1 & 472 & 1.5 & 7.5 & $18 / 08 / 2020$ \\
\hline India ${ }^{a}$ & 1622 & 4.35 & 42 & 10.4 & 22.7 & 05/08/2020 \\
\hline Chile & 15 & 4.1 & 576 & 0.7 & 4.9 & $05 / 08 / 2020$ \\
\hline Colombia & 29 & 2.9 & 334 & 0.9 & 7.8 & 05/08/2020 \\
\hline Indonesia ${ }^{a b}$ & 88 & 1.3 & 25 & 5.2 & 12.7 & 05/05/2020 \\
\hline Philippines $^{\text {ac }}$ & 40 & 1.2 & 29 & 4.3 & 13.5 & 05/08/2020 \\
\hline Argentina ${ }^{a}$ & 13 & 1.1 & 153 & 0.7 & 6.4 & $10 / 08 / 2020$ \\
\hline Spain ${ }^{a}$ & 5 & 0.8 & 616 & 0.1 & 1.7 & $21 / 05 / 2020$ \\
\hline United States of America ${ }^{a}$ & 46 & 0.8 & 533 & 0.1 & 3.5 & 01/08/2020 \\
\hline United Kingdom & 7 & 0.6 & 623 & 0.1 & 2.6 & 05/08/2020 \\
\hline Sweden ${ }^{a}$ & 1 & 0.6 & 571 & 0.1 & 1.5 & 05/08/2020 \\
\hline Italy & 4 & 0.6 & 586 & 0.1 & 2 & $28 / 07 / 2020$ \\
\hline France & 4 & 0.35 & 454 & 0.1 & 2.54 & $12 / 07 / 2020$ \\
\hline Canada $^{a}$ & 1 & 0.1 & 245 & 0.1 & 3.4 & $26 / 08 / 2020$ \\
\hline Germany ${ }^{a}$ & 1 & 0.1 & 111 & 0.1 & 2.2 & 05/08/2020 \\
\hline Australia ${ }^{a}$ & 0 & 0 & 19 & 0 & 2.3 & 05/08/2020 \\
\hline Austria & 0 & 0 & 83 & 0 & 2.1 & 05/08/2020 \\
\hline Finland & 0 & 0 & 61 & 0 & 1 & $05 / 08 / 2020$ \\
\hline Greece & 0 & 0 & 22 & 0 & 2.6 & 05/08/2020 \\
\hline Republic of Korea & 0 & 0 & 6 & 0 & 1.5 & 05/08/2020 \\
\hline
\end{tabular}

${ }^{a}$ Countries that do not report data disaggregated by quinquennial age groups. ${ }^{b}$ The latest population data were available in 2010 . ${ }^{\mathrm{c}}$ The latest population data were available in 2015 .

respectively), while a moderate or no correlation was found with COVID-19 mortality in the general population $(r=0.47, p=0.02$; and $r=0.19, p=0.38$, respectively) (Table 3).

\section{Discussion}

COVID-19 mortality in children is minimal in comparison to the adult population. However, we found significant heterogeneity between countries. Several factors should be explored to explain this variability. This report was elaborated with available data from different sources, and differences in reporting systems of epidemiological information may be accountable for some variation.

Remarkably, the highest pediatric mortality rates are among upper-middle-income countries in contrast with high-income countries (data for low- and lower-middle-income countries were not available). Similarly, high-income countries with high mortality 
Table 2. COVID-19 mortality rates by quinquennial age groups and country

\begin{tabular}{|c|c|c|c|c|c|c|}
\hline \multirow[t]{3}{*}{ Country } & \multicolumn{6}{|c|}{ COVID-19 } \\
\hline & \multicolumn{2}{|c|}{ Population aged 0-4 years } & \multicolumn{2}{|c|}{ Population aged 5-9 years } & \multicolumn{2}{|c|}{ Population aged $10-14$ years } \\
\hline & Deaths & $\begin{array}{l}\text { Mortality rate } \\
\text { (per million) }\end{array}$ & Deaths & $\begin{array}{l}\text { Mortality rate } \\
\text { (per million) }\end{array}$ & Deaths & $\begin{array}{l}\text { Mortality rate } \\
\text { (per million) }\end{array}$ \\
\hline Peru & 40 & 16.04 & 29 & 10.96 & 25 & 9.57 \\
\hline India ${ }^{a}$ & 1519.1 & 13.47 & 20.5 & 0.16 & 82.2 & 0.62 \\
\hline Mexico & 108 & 9.85 & 25 & 2.25 & 36 & 3.22 \\
\hline Ecuador $^{b}$ & 11 & 7.52 & 7 & 4.58 & 7 & 4.55 \\
\hline Chile & 9 & 7.24 & 3 & 2.40 & 3 & 2.52 \\
\hline Colombia & 15 & 4.94 & 9 & 2.70 & 5 & 1.38 \\
\hline Brazilab $^{a}$ & 38.2 & 2.77 & 103.8 & 6.93 & 263.1 & 15.33 \\
\hline Philippines $^{\text {ac }}$ & 26 & 2.40 & 7 & 0.65 & 7 & 0.67 \\
\hline Indonesia ${ }^{a b}$ & 47.4 & 2.09 & 22.3 & 0.96 & 18.4 & 0.81 \\
\hline United States of America & 25.3 & 1.28 & 8.1 & 0.40 & 12.2 & 0.58 \\
\hline Argentina $^{a}$ & 3.5 & 0.94 & 3.5 & 0.94 & 5.5 & 1.56 \\
\hline Italy & 2 & 0.82 & 2 & 0.82 & 0 & 0 \\
\hline United Kingdom & 3 & 0.76 & 1 & 0.24 & 3 & 0.79 \\
\hline Sweden $^{\mathrm{a}}$ & 0.4 & 0.66 & 0.6 & 0.98 & 0 & 0 \\
\hline Spain $^{a}$ & 0.9 & 0.43 & 1.9 & 0.78 & 2.5 & 1.02 \\
\hline France & 1 & 0.28 & 2 & 0.5 & 1 & 0.25 \\
\hline Germany ${ }^{a}$ & 1 & 0.26 & 0 & 0 & 0 & 0 \\
\hline Canada $^{a}$ & 0.25 & 0.13 & 0.25 & 0.12 & 0.25 & 0.13 \\
\hline Australia & 0 & 0 & 0 & 0 & 0 & 0 \\
\hline Austria & 0 & 0 & 0 & 0 & 0 & 0 \\
\hline Finland & 0 & 0 & 0 & 0 & 0 & 0 \\
\hline Greece & 0 & 0 & 0 & 0 & 0 & 0 \\
\hline Republic of Korea & 0 & 0 & 0 & 0 & 0 & 0 \\
\hline
\end{tabular}

${ }^{a}$ Countries that do not report data disaggregated by quinquennial age groups. ${ }^{b}$ The latest population data were available in 2010. ${ }^{\mathrm{C} T h e}$ latest population data were available in 2015.

Table 3. Spearman correlation coefficient between COVID-19 pediatric mortality, COVID-19 general mortality, neonatal mortality in 2018, and COVID-19 pediatric/general mortality rate ratio

\begin{tabular}{|l|c|c|c|}
\hline COVID-19 mortality rate in $<15$ years of age population & $\begin{array}{c}\text { COVID-19 mortality rate in } \\
<15 \text { years of age population }\end{array}$ & $\begin{array}{c}\text { COVID-19 mortality rate } \\
\text { in the general population }\end{array}$ & $\begin{array}{c}\text { Neonatal mortality } \\
\text { in } 2018\end{array}$ \\
\hline COVID-19 mortality rate in general population & - & $0.47^{\mathrm{b}}$ & $0.77^{\mathrm{a}}$ \\
\hline COVID-19 pediatric/general mortality rate ratio & $0.47^{\mathrm{b}}$ & - & -0.03 \\
\hline
\end{tabular}


rates in the general population showed low COVID-19 pediatric/general mortality rate ratio (adjusted for age).

In most countries, the pediatric population's COVID19 mortality rate is concentrated in the $<5$-year-old population. Brazil has a disproportionately high mortality rate in adolescents, and the causes of this must be studied. In Mexico, about half of the deaths in the 0-4 age group are in infants $<1$ year old. It is important to disaggregate data by age to estimate the share of child mortality, which corresponds to neonatal and infant mortality.

Child, infant, and neonatal mortality are known indicators of the quality of health-care systems ${ }^{16}$. It is noticeable that COVID-19 pediatric mortality and COVID-19 pediatric/general rate ratio are strongly correlated with historical basal neonatal mortality, while they are only moderately correlated with COVID-19 general mortality. These findings suggest an important role of social health determinants and the quality of health-care systems in discrepancies of COVID-19 pediatric mortality rates between countries. The relative importance of this set of factors over biological factors remains to be established.

\section{Ethical disclosures}

Protection of human and animal subjects. The authors declare that no experiments were performed on humans or animals for this study.

Confidentiality of data. The authors declare that they have followed the protocols of their work center on patient data publication.

Right to privacy and informed consent. The authors declare that no patient data appear in this article.

\section{Conflicts of interest}

The authors declare no conflicts of interest.

\section{Funding}

None.

\section{References}

1. Onder G, Rezza G, Brusaferro S. Case-fatality rate and characteristics of patients dying in relation to COVID-19 in Italy. JAMA. 2020;323:1775-6.

2. Richardson S, Hirsch JS, Narasimhan M, Crawford JM, McGinn T, Davidson $\mathrm{KW}$, et al. Presenting characteristics, comorbidities, and outcomes among 5700 patients hospitalized with COVID-19 in the New York City area. JAMA. 2020:323:2052-9.

3. Williamson EJ, Walker AJ, Bhaskaran K, Bacon S, Bates C, Morton CE, et al. Factors associated with COVID-19-related death using Open SAFELY. Nature. 2020;584:430-6.

4. Petrilli CM, Jones SA, Yang J, Rajagopalan H, O'Donnell L, Chernyak Y, et al. Factors associated with hospital admission and critical illness among 5279 people with coronavirus disease 2019 in New York City: prospective cohort study. BMJ. 2020;369:m1966.

5. Zhou F, Yu T, Du R, Fan G, Liu Y, Liu Z, et al. Clinical course and risk factors for mortality of adult inpatients with COVID-19 in Wuhan, China: a retrospective cohort study. Lancet. 2020;395:1054-62.

6. Liguoro I, Pilotto C, Bonanni M, Ferrari M, Pusiol A, Nocerino A, et al. SARS-COV-2 infection in children and newborns: a systematic review. Eur J Pediatr. 2020;179:1029-46.

7. AAP News, Jenco M. Study: $33 \%$ of Children Hospitalized with COVID- 19 Admitted to ICU. Illinois: American Academy of Pediatrics News; 2020. Available from: https://www.aappublications.org/news/2020/08/07/covid19hospitalization080720.

8. AAP News, Jenco M. Study: Hispanic, Black, Low-income Children Had the Highest Rates of SARS-CoV-2. Illinois: American Academy of Pediatrics News; 2020. Available from: https://www.aappublications.org/ news/2020/08/05/covid19disparities080520\#: :text=Children\%20in\%20 the $\% 20$ Washington $\% 2$ C $\% 20 D . C$., households $\% 2 C \% 20$ a $\% 20$ new $\% 20$ study\%20found.

9. Riffe T, Acosta E, Aburto JM, Alburez GD, Altová A, Basellini U, COVerAGE-DB Project Team. COVerAGE-DB: a database of COVID-19 cases and deaths. medRxiv. 2020; DOI: 10.17605/OSF.IO/MPWJQ.

10. Ministerio de Salud. Información Epidemiológica. Buenos Aires: Ministerio de Salud Argentina; 2020. Available from: https://www.argentina.gob. ar/salud/coronavirus-COVID-19/sala-situacion.

11. Ministerio de Salud. Plataforma Nacional de Datos Abiertos. Lima: Ministerio de Salud de Perú; 2020. Available from: https://www.datosabiertos. gob.pe/dataset/fallecidos-por-covid-19-ministerio-de-salud-minsa.

12. Government of Canada. Coronavirus Disease, 2019 (COVID-19). Epidemiology Update: Government of Canada; 2020. Available from: https:// www.open.canada.ca/data/en/dataset/955b9057-b6a7-475c-ae00$64 \mathrm{e} 821 \mathrm{~d} 21612$.

13. Gobierno de México. Datos Abiertos. Dirección General de Epidemiología: dirección General de Epidemiología, Secretaría de Salud. Ciudad de México: Gobierno de México; 2020. Available from: https://www.gob.mx/ salud/documentos/datos-abiertos-152127.

14. UN Data A World of Information: United Nations Statistics Division; 2020. Available from: http://www.data.un.org/Data.aspx?d=POP\&f=tableCode\%3A22\#POP.

15. WHO Coronavirus Disease (COVID-19) Dashboard: Geneva: World Health Organization; 2020. Available from: https://www.covid19.who.int.

16. Richardus JH, Graafmans WC, Verloove-Vanhorick SP, Mackenbach JP. The perinatal mortality rate as an indicator of quality of care in international comparisons. Med Care. 1998;36:54-66. 